\title{
Evaluation of microbial shifts caused by a silver nanomaterial: comparison of four test systems
}

\author{
Kerstin Hund-Rinke ${ }^{{ }^{*}}\left(\mathbb{D}\right.$, Anna Hümmler ${ }^{1}$, Ruben Schlinkert ${ }^{1}$, Franziska Wege ${ }^{1}$ and Gabriele Broll ${ }^{2}$
}

\begin{abstract}
Background: Before chemicals, pesticides and biocides are registered and approved, their effects on soil microorganisms must be tested, specifically their impact on nitrogen transformation. Following a request from the European Food Safety Authority (EFSA), the Panel on Plant Protection Products and their Residues provided an opinion document evaluating the science behind the risk assessment of plant protection products in the context of soil-dwelling organisms. The EFSA document concludes that the most relevant community-based microbial test systems should cover the widest possible range of metabolic processes without compromising test sensitivity. The EFSA document refers to the MicroResp test system, stating that although it has not been used to study the effects of pesticides on soil microbial processes, its capability should be investigated in the future. In the scope of harmonization approaches, the recommendations in the EFSA document covering pesticides could also influence the risk assessment and regulation of other kinds of chemicals, including silver nanomaterials. We therefore used the silver nanomaterial NM-300K as a model substance to evaluate the sensitivity of three functional tests covering the activities of different microbial fractions: (1) the potential ammonium oxidation (PAO) test, which considers the first step in nitrification; (2) the MicroResp test, which determines respiratory activity by measuring $\mathrm{CO}_{2}$ evolution; and (3) a colorimetric test system for exoenzyme activity. We also surveyed bacterial $16 \mathrm{~S}$ rRNA sequence diversity by next-generation sequencing (NGS).

Results: There was no major difference in the general sensitivity of the tests, each of which revealed significant effects at silver nanomaterial concentrations of at least $1.67 \mathrm{mg} / \mathrm{kg}$. The PAO test was a robust and sensitive indicator of toxicity, and concentration-effect relationships were calculated for every time interval. The effects on respiration and exoenzyme activities were more variable. Among the three functional tests, the selected exoenzyme activities showed the weakest concentration-effect relationships, although silver concentrations were clearly related to two of the four activities we tested (glucosidase and arylsulfatase). We also observed a relationship between silver concentrations and respiration activity on glucose, cellobiose and alanine substrates. The bacterial orders identified by NGS differed in sensitivity to the silver nanomaterial. We found that the adverse impact on nitrifiers matched the inhibition of PAO activity. $\mathrm{EC}_{50}$ values calculated for each functional test did not identify a generally superior method.

Conclusion: We found that all four test approaches were similar in sensitivity towards the model silver nanomaterial, an ion-releasing substance. We observed advantages and limitations for each test, which must be considered when selecting tests for the registration or approval of substances. It is unclear whether the sensitivity of the tests would be comparable when testing substances that do not release ions. The regulatory assessment of metabolic profiles requires further consideration in terms of substrate selection. Finally, for tests performed in multiwell plates with small quantities of soil, the quality of the concentration-effect relationships must be studied in more detail.
\end{abstract}

\footnotetext{
*Correspondence: kerstin.hund-rinke@ime.fraunhofer.de

${ }^{1}$ Fraunhofer Institute for Molecular Biology and Applied Ecology IME, Auf dem Aberg 1, 57392 Schmallenberg, Germany

Full list of author information is available at the end of the article
} 
Keywords: Hazard assessment, Microbial toxicology, Nanoparticles, Soil ecotoxicology

\section{Background}

There is a growing debate on the role of soil ecotoxicology and biodiversity in risk assessment [1-3]. Soils contain abundant and diverse microbial populations that facilitate ecosystem functions such as nutrient cycling [4]. The registration and approval of substances such as chemicals, pesticides and biocides therefore requires tests for potential effects on these organisms [5-7]. Such tests focus on the evaluation of microbial nitrogen transformation as per OECD Guideline 216 [8]. This approach provides information about the populations of organisms capable of ammonification and nitrification.

Following a request from the European Food Safety Authority (EFSA), the Panel on Plant Protection Products and their Residues prepared an opinion document on the science behind the risk assessment of plant protection products, evaluating the tests used to determine effects on soil-dwelling organisms [1]. The document identifies specific protection goals to which various phylogenetic and functional microbial groups contribute, including biodiversity, genetic resources, cultural services, nutrient cycling, and pest control. The document recommends that the most relevant community-based microbial test systems should cover the broadest possible range of metabolic processes without compromising test sensitivity. However, current community-based functional tests for effects on nitrogen transformation (mandated in Europe and North America) and $\mathrm{CO}_{2}$ evolution as a measure of general microbial activity (mandated in North America) are crude and lack the sensitivity to indicate toxic effects against essential microbial processes carried out only by a small number of specialized microorganisms.

The EFSA document refers specifically to the MicroResp test system, which measures microbial respiration by detecting the evolution of $\mathrm{CO}_{2}$ [9]. Although this system has not yet been used to study the effects of pesticides on soil microbial processes, the EFSA document recommends further evaluation. The impact of soil type, assay duration and soil water content on MicroResp results have been investigated thoroughly, and the method is considered suitable for soil ecotoxicity studies [10]. The MicroResp system measures $\mathrm{CO}_{2}$ evolution in a microtiter plate format. It was developed for short-term measurements (4-6 h) with initial and endpoint readings $[9,11]$. However, OECD Guideline 217 [12] recommends that soil respiration should be measured continuously or at hourly or two-hourly intervals for $12 \mathrm{~h}$ after the addition of glucose, and is based on the testing of larger quantities of soil ( 100 g), which limits the number of replicates. In contrast, the 96-well format of the MicroResp system works with smaller samples and thus allows many different carbon sources to be used in parallel to test for substrate-induced respiration activity, thus creating a metabolic profile of the microbial population.

Other miniaturized tests, such as those complying with ISO test guidelines [13, 14], focus on the measurement of exoenzyme activity. Enzymes in the soil are often associated with proliferating cells, but they may also be free in solution or bound to humic colloids and clay minerals [15]. The dynamics of these different enzyme pools and their contribution to ecosystem processes remain uncertain [16]. Enzyme stability is influenced by geochemical factors, by the presence of proteases, and by the intrinsic properties of the enzyme itself. For example, $\beta$-glucosidase is a stable enzyme, whereas the levels of $\alpha$-glucosidase fall quickly after cell death indicating that constant synthesis is necessary to balance its rapid degradation [17]. An inter-laboratory comparison of the MicroResp system and a multi-enzyme assay using fluorogenic substrates showed that both methods are prone to inter-laboratory variation [18]. However, following the same strict protocol can minimize such differences [19].

The development of miniaturized, high-throughput test systems has increased our understanding of microbial diversity in the environment [20-22]. However, the relationship between microbial diversity and soil functions remains unclear because the same functions can be fulfilled by many taxonomic groups [4, 23, 24]. Confining the functions of specific phylogenetic units is still a challenge, and the EFSA opinion paper states that although various methods can be used to measure soil microbial properties in terms of abundance, functions and community structure, further adjustments are necessary for use in risk assessment [1].

The registration and approval of substances currently requires tests to determine the impact on soil nitrogen transformation, as per OECD test guideline 216 [8]. Soil is incubated with the test substance and an organic nitrogen source, and periodic measurements are taken to record the concentrations of ammonium, nitrite and nitrate. These nitrogen-containing inorganic compounds are generated by several transformation processes (e.g., microbial ammonification, nitrification and nitrogen fixation) and the test therefore integrates a number of microbial activities. In contrast to the method described in the OECD test guideline, the potential ammonium oxidation (PAO) test [25] is suitable for the assessment of toxic 
ion-releasing substances [26]. A soil sample is mixed with the test substance, and a nutrient source $\left(\mathrm{NH}_{4}{ }^{+}\right)$is added at three time points so that $\mathrm{NO}_{2}{ }^{-}$(as indicator of transformation activity) can be determined after a short incubation, generating a profile of stimulation and inhibition during the 28 days of the test.

To assess the suitability of different tests for functional and genomic microbial diversity in the context of risk assessment, we compared the PAO test [25] with the MicroResp system [9] and a colorimetric test for exoenzyme activity [13]. For the MicroResp and exoenzyme tests, we selected four substrates (two of which were directly comparable between the tests). We complemented the three functional tests with a survey of bacterial genomic diversity, sampling the $16 \mathrm{~S}$ rRNA gene by next-generation-sequencing (NGS). In light of current harmonization efforts, the tests currently applied to plant protection products will probably extend to cover other substances, including biocides and chemicals. Therefore, instead of a conventional pesticide, we selected a silver nanomaterial as an environmentally relevant model substance [27] with well-known antibacterial activity [28-30].

\section{Methods}

Soil

The experiments were carried out using the reference soil RefeSol 01A (sieved $\leq 2 \mathrm{~mm}$ ), which is a loamy, moderately acidic sand ( $73 \%$ sand, $22 \%$ silt and $5 \%$ clay; $\mathrm{pH} 5.6$ ) with a low organic matter content $\left(C_{\text {org }}=1.1 \%\right)$. Appropriate amounts of soil were sampled 1-4 weeks before the test. If the soil was too wet for sieving, it was dried at room temperature to $20-30 \%$ of the maximum water holding capacity $\left(\mathrm{WHC}_{\max }\right)$ with periodic turning to avoid surface drying. If the tests did not start immediately after sieving, the soil was stored in the dark at $4{ }^{\circ} \mathrm{C}$ under aerobic conditions.

\section{Spiking and incubation}

The silver nanomaterial NM-300K was used as proposed by the OECD Sponsorship Programme [31]. This is a colloidal silver dispersion with a nominal silver content of $10 \%(\mathrm{w} / \mathrm{w})$ and a particle size of $\sim 15 \mathrm{~nm}$ with a narrow size distribution (99\%). A second particle size of $5 \mathrm{~nm}$, which is much less abundant (1\%), was identified by transmission electron microscopy [32]. The particles are dispersed in a mixture of a stabilizing agents (NM-300K DIS) comprising $4 \%(\mathrm{w} / \mathrm{w})$ each of polyoxyethylene glycerol tri-oleate and polyoxyethylene sorbitan monolaurate (Tween-20). We added $8 \mathrm{~mL}$ of deionized water to a vial containing $2 \mathrm{~mL} \mathrm{NM}-300 \mathrm{~K}$ and homogenized the suspension in an ultrasonic bath. The required amount was mixed with $10 \mathrm{~g}$ air-dried soil and added to $990 \mathrm{~g}$ soil (dry matter) which had been adjusted to $10-15 \%$ $\mathrm{WHC}_{\max }$. After thorough mixing, the water content was adjusted to $45 \% \mathrm{WHC}_{\max }$. Five test concentrations of NM-300K were prepared $(0.19,0.56,1.67,5$ and $15 \mathrm{mg} /$ $\mathrm{kg})$ as well as two replicates of the untreated control. The soil (1000 g dry matter per replicate) was incubated under aerobic conditions at $20 \pm 2{ }^{\circ} \mathrm{C}$ for 4 weeks. Every 7 days, any evaporated water was replaced. Microbial activity was determined after 7, 14 and 28 days of incubation. Genomic diversity was measured after an incubation period of 28 days.

\section{Microbial test systems PAO test}

The short-term PAO test was performed according to ISO guideline 15685 [25]. Four 250-mL Erlenmeyer flasks per treatment were filled with $25 \mathrm{~g}$ dry matter of spiked soil along with four matching controls. The vessels were incubated in the dark at $20 \pm 2{ }^{\circ} \mathrm{C}$ for $24 \mathrm{~h}$ and then mineral test medium $\left(0.56 \mathrm{mM} \mathrm{KH} \mathrm{PO}_{4}, 1.44 \mathrm{mM} \mathrm{K}_{2} \mathrm{HPO}_{4}\right.$, $\left.5 \mathrm{mM} \mathrm{NaClO}_{3}, 1.50 \mathrm{mM}\left(\mathrm{NH}_{4}\right)_{2} \mathrm{SO}_{4}\right)$ was added to make up the volume to $100 \mathrm{~mL}$. The slurries were incubated on an orbital shaker at $25 \pm 2{ }^{\circ} \mathrm{C}$, and $10-\mathrm{mL}$ samples were removed after 2 and $6 \mathrm{~h}$. The samples were supplemented with $10 \mathrm{~mL} 4 \mathrm{M} \mathrm{KCl}$ and filtered, and the nitrite levels in the filtrate were determined by spectrophotometry at $530 \mathrm{~nm}$.

\section{MicroResp system}

Substrate-induced respiration activity was measured using glucose and cellobiose to represent the carbon cycle, and the amino acids alanine and cysteine to represent the nitrogen and sulfur (cysteine) cycles. The test was performed according to the manufacturer's protocol. For each substrate, eight replicates were prepared. The absorbance of the detection plates containing a detection gel with an indicator dye was measured at $570 \mathrm{~nm}$ before contact with the Deepwell plates. After an incubation period of $6 \mathrm{~h}$ at $25^{\circ} \mathrm{C}$, the detection plates were scanned again, and the quantity of evolved $\mathrm{CO}_{2}$ was calculated.

\section{Exoenzyme test}

The activities of $\beta$-glucosidase, arylsulfatase, arylamidase and phosphatase were measured using colorimetric substrates in 96-well plates according to the ISO test guideline 20130 [13]. For each test, we transferred two replicate aliquots of soil dry matter $(4 \mathrm{~g})$ to Erlenmeyer flasks and added $25 \mathrm{~mL}$ deionized water. The mixture was homogenized for 10 min using a magnetic bar. We transferred $125-\mu \mathrm{L}$ aliquots from these mixtures to the wells of microtiter plates, with separate plates for each enzyme. We prepared four wells per sample for each enzyme, one as a control and three for the substrate. The plates were 
incubated for $30 \mathrm{~min}$ (phosphatase), $1 \mathrm{~h}$ ( $\beta$-glucosidase) or $4 \mathrm{~h}$ (arylsulfatase) before adding $25 \mu \mathrm{L} \mathrm{CaCl}_{2}$ and 100 $\mu \mathrm{L}$ Tris ( $\mathrm{pH} 12)$ as stop reagents to each well, and $23 \mu \mathrm{L}$ of substrate to the control. The plates were then centrifuged $\left(5 \mathrm{~min}, 1500 \mathrm{~g}, 20^{\circ} \mathrm{C}\right.$ ) and we transferred $200 \mu \mathrm{L}$ of the supernatant from each well to new plates before reading the absorbance at $405 \mathrm{~nm}$. The reaction with arylamidase was stopped after $2 \mathrm{~h}$ by adding $150 \mu \mathrm{L} 96 \%$ ethanol. After adding substrate to the control followed by centrifugation as described above, we transferred $100 \mu \mathrm{L}$ of the supernatant from each well to new plates, added 100 $\mu \mathrm{L}$ acidified ethanol and $100 \mu \mathrm{L} p$-dimethylaminocinnamaldehyde (DMCA), incubated the plates for $20 \mathrm{~min}$ at room temperature in the dark and read the absorbance at $540 \mathrm{~nm}$. Enzymatic activity was calculated according to ISO test guideline 20130.

\section{Statistical analysis of microbial activities}

Statistical analysis and the calculation of $\mathrm{EC}_{10}$ and $\mathrm{EC}_{50}$ values were carried out using ToxRat Pro v3.3.0 for ecotoxicity response analysis (ToxRat Solutions, Alsdorf, Germany). The normal sigmoid model (three parameters) was selected for the calculation.

\section{Microbial genomic diversity}

DNA was extracted from each soil sample $(\sim 0.25 \mathrm{~g}$ fresh weight) in duplicate using the PowerSoil DNA Isolation Kit (MoBio Laboratories, Carlsbad, CA, USA). The yield and purity were measured using a NanoDrop ND-2000 spectrophotometer (Thermo Fisher Scientific, Waltham, MA, USA). The duplicate DNA extracts for each soil sample were mixed and pooled to generate a unique sample for NGS analysis. DNA from each treatment was submitted to Eurofins Scientific (Luxembourg) for $16 \mathrm{~S}$ amplicon sequencing using the Illumina Miseq platform. Briefly, amplicons of the hypervariable regions $\mathrm{V} 3-\mathrm{V} 4$ were generated by PCR using forward primer $5^{\prime}$-TAC GGG AGG CAG CAG-3' [33] and reverse primer 5'-CCA GGG TAT CTA ATC C-3' [34]. In a second round of PCR, the adapter overhang nucleotide sequences for the forward and reverse index primers were added, before amplicons were purified using AMPure CP beads (Beckman Coulter, Brea, CA, USA) and amplified by PCR using Nextera CT index primers (Illumina, San Diego, CA, USA). The indexed samples were purified using AMPure XP beads (Beckman Coulter), quantified and pooled in equal quantities. The pooled library was quantified using an Agilent 2100 Bioanalyzer (Agilent Technologies, Santa Clara, CA, USA) and sequenced using v3 chemistry $(2 \times 300$ bp paired-end reads). The sequences were then demultiplexed, primer sequences were clipped, forward and reverse reads were merged, and quality filters were applied. Reads containing ambiguous bases and chimeric reads were removed [35]. The remaining highquality reads were processed using minimum entropy decomposition [36, 37], allowing dataset decomposition at single-nucleotide resolution. Taxonomic information was assigned to each operational taxonomic unit (OTU) using DC-MEGABLAST (reference database: NCBI_nt). Further processing of OTUs was performed using QIIME [38].

Microorganisms were identified up to the order level. Based on these values, the Shannon index $\left(\mathrm{H}^{\prime}\right)$ and the species evenness $\left(\mathrm{E}_{\mathrm{H}}\right)$ were calculated to describe diversity, and Stander and Steinhaus similarity indices [39] were determined in Community Analysis v4.3. To identify changes due to the NM-300K treatment, each order in the treated and untreated samples was normalized to the mean value of the controls. Deviations between the treatments and controls were marked using colors representing six ranges $(<0.01,<0.1,<0.5,0.5-2,>2$, and $>10$, the first three values corresponding to reductions of $>99 \%,>90 \%$ and $>50 \%$ in the treated samples vs controls, and the last three values representing fold-increases in the treated samples vs controls). $\mathrm{EC}_{10}$ and $\mathrm{EC}_{50}$ values were calculated as described above.

\section{Results}

\section{Functional tests}

A clear concentration-effect relationship was observed in the PAO test (Fig. 1, Additional file 1: Table S1) with significant effects recorded at NM-300K concentrations $\geq 1.67 \mathrm{mg} / \mathrm{kg}$. At a concentration of $1.67 \mathrm{mg} / \mathrm{kg}$, the effect of NM-300K exposure increased over time, but the increase was less pronounced at higher concentrations (5 and $15 \mathrm{mg} / \mathrm{kg}$ ) because strong effects were already observed at the start of the test. Given the strong inhibition of PAO activity at the two highest NM-300K concentrations, the EC values declined only slightly during the incubation period of 28 days, with narrow but nevertheless overlapping confidence intervals (Table 1).

We also observed concentration-effect relationships for the substrate-induced respiration activities measured using the MicroResp system. The relationships were clear for the tests on all four substrates at the start of the experiment, but were less pronounced for the amino acid substrates at the end (Fig. 2, Additional file 1: Table S2). The concentration-effect relationships for the two sugars were similar at all three sampling points, with clear concentration-effect curves observed after incubation periods of 7 and 28 days. The concentration-effect relationships for the two amino acids were similar after 14 and 28 days but differed on day 7 . After 14 days, effects on all four substrates were observed mainly for the two highest test concentrations. Due to the limited concentration-effect relationships, $\mathrm{EC}_{10}$ and $\mathrm{EC}_{50}$ values could 


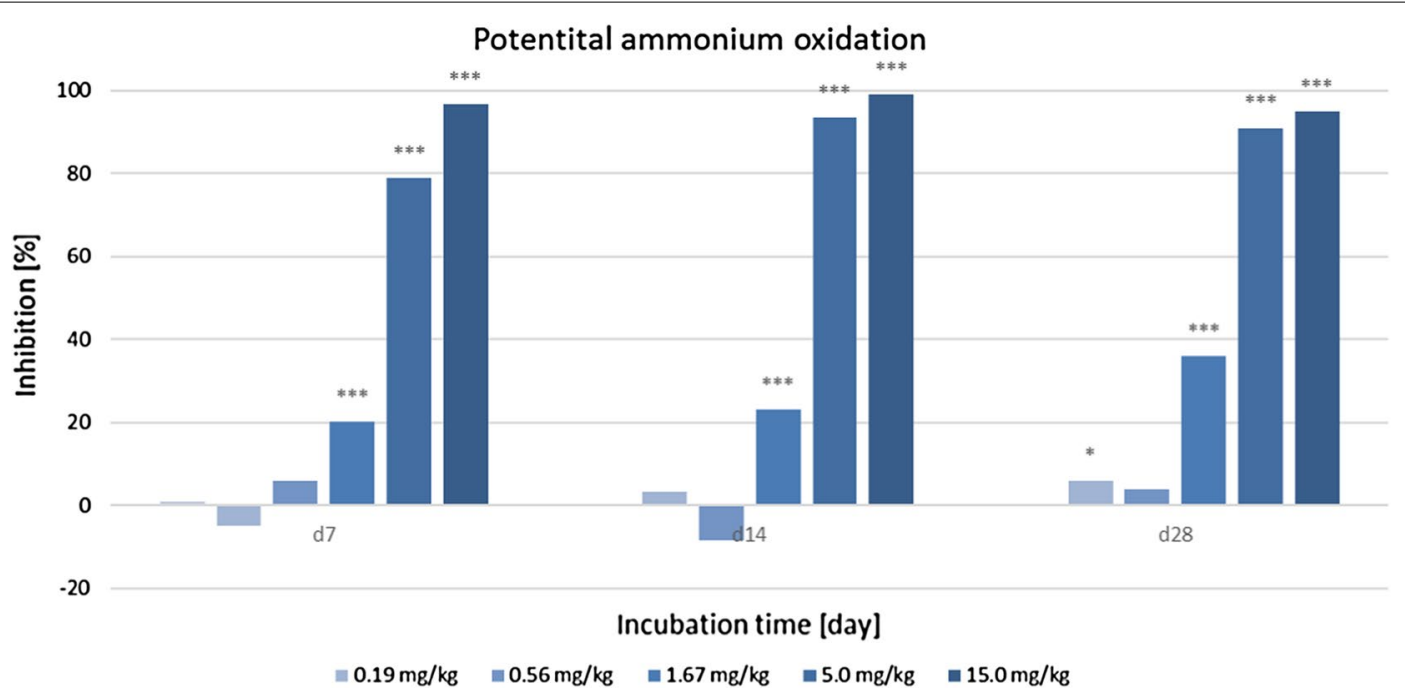

Fig. 1 Effect of the silver nanomaterial NM-300K on potential ammonium oxidation activity. Statistical significance $(a=0.05)$ is indicated on the bars representing inhibition: ${ }^{*} 0.01 \leq p<0.05 ;{ }^{* *} 0.001 \leq p<0.01$; ${ }^{* * *} p<0.001$

Table $1 \mathrm{EC}_{10}$ and $\mathrm{EC}_{50}$ values $[\mathrm{mg} / \mathrm{kg}$ ] of the silver nanomaterial NM-300K for the inhibition of potential ammonium oxidation activity

\begin{tabular}{lcl}
\hline Day & $\mathrm{EC}_{\mathbf{1 0}}[\mathbf{m g} / \mathbf{k g}]^{\mathbf{a}}$ & $\mathrm{EC}_{\mathbf{5 0}}[\mathbf{m g} / \mathbf{k g}]^{\mathbf{a}}$ \\
\hline 7 & $1.18[0.99-1.41]$ & $2.90[2.62-3.21]$ \\
14 & $0.420[0.35-0.51]$ & $0.79[0.70-0.89]$ \\
28 & $0.33[0.28-0.39]$ & $0.71[0.65-0.77]$ \\
\hline
\end{tabular}

a Values in brackets indicate $95 \%$ confidence limit

not be calculated for every carbon source and sampling interval. The values for glucose and cellobiose indicated slightly decreasing toxicity, with overlapping confidence intervals (Table 2).

The effects on exoenzyme activities varied over time and were specific for each enzyme (Fig. 3, Additional file 1: Table S3). Concentration-effect relationships were clearly observed for the glucosidase and arylsulfatase activities, with decreasing effects during the incubation period for the two lower test concentrations. $\mathrm{EC}_{10}$ values could not be calculated for every sampling interval, and $\mathrm{EC}_{50}$ values ranged from 2 to $22 \mathrm{mg} / \mathrm{kg}$ for both enzymes (Table 3). The effects on arylamidase and phosphatase activities varied over time, but there was no evidence of concentration-effect relationships so we were unable to calculate EC values. Medium concentrations of NM$300 \mathrm{~K}$ had the greatest impact on arylamidase activity, with a concentration-dependent decrease at lower and higher concentrations at the end of the test. Phosphatase activity was not affected at the two lowest NM-300K test concentrations after 28 days, whereas the three higher concentrations each caused $\sim 25 \%$ inhibition despite the $\sim$ tenfold concentration range $(1.67-15 \mathrm{mg} / \mathrm{kg})$.

\section{Genomic diversity test}

We used NGS to survey bacterial diversity by sequencing the 16S rRNA gene in each soil sample (Fig. 4, Additional file 1: Table S4). Bacterial orders differing in representation between samples spiked with NM-300K and untreated controls are highlighted in Table 4. The total abundance of bacteria across all samples varied by a factor of 1.7, but there was no overall concentrationeffect relationship. In the two control replicates, there was $a<15 \%$ difference in abundance between samples in $60 \%$ of the bacterial orders. Increasing concentrations of NM-300K led to the depletion of some orders but the enrichment of others. For example, the abundance of Desulfovibrionales in the control samples was low, and this order was eliminated in all samples containing NM-300K. Propionibacteriales were depleted by the nanomaterial in a concentration-dependent manner, with effects observed even at the lowest test concentration, whereas Rhodospirillales were more resilient and depletion was only evident at higher test concentrations. For three orders (Propionibacteriales, Rhodospirillales, and Gemmatimonadales) the progressive depletion with increasing concentrations of NM-300K allowed us to calculate reliable $\mathrm{EC}_{50}$ values of $0.72-19.5 \mathrm{mg} / \mathrm{kg}$, confirming the order-specific differences in sensitivity (Table 5). As well as showing clear concentration-effect relationships, some orders (e.g., Sphingobacteriales and Cytophagales) showed the maximum deviation from the control at medium concentrations of NM-300K. The 

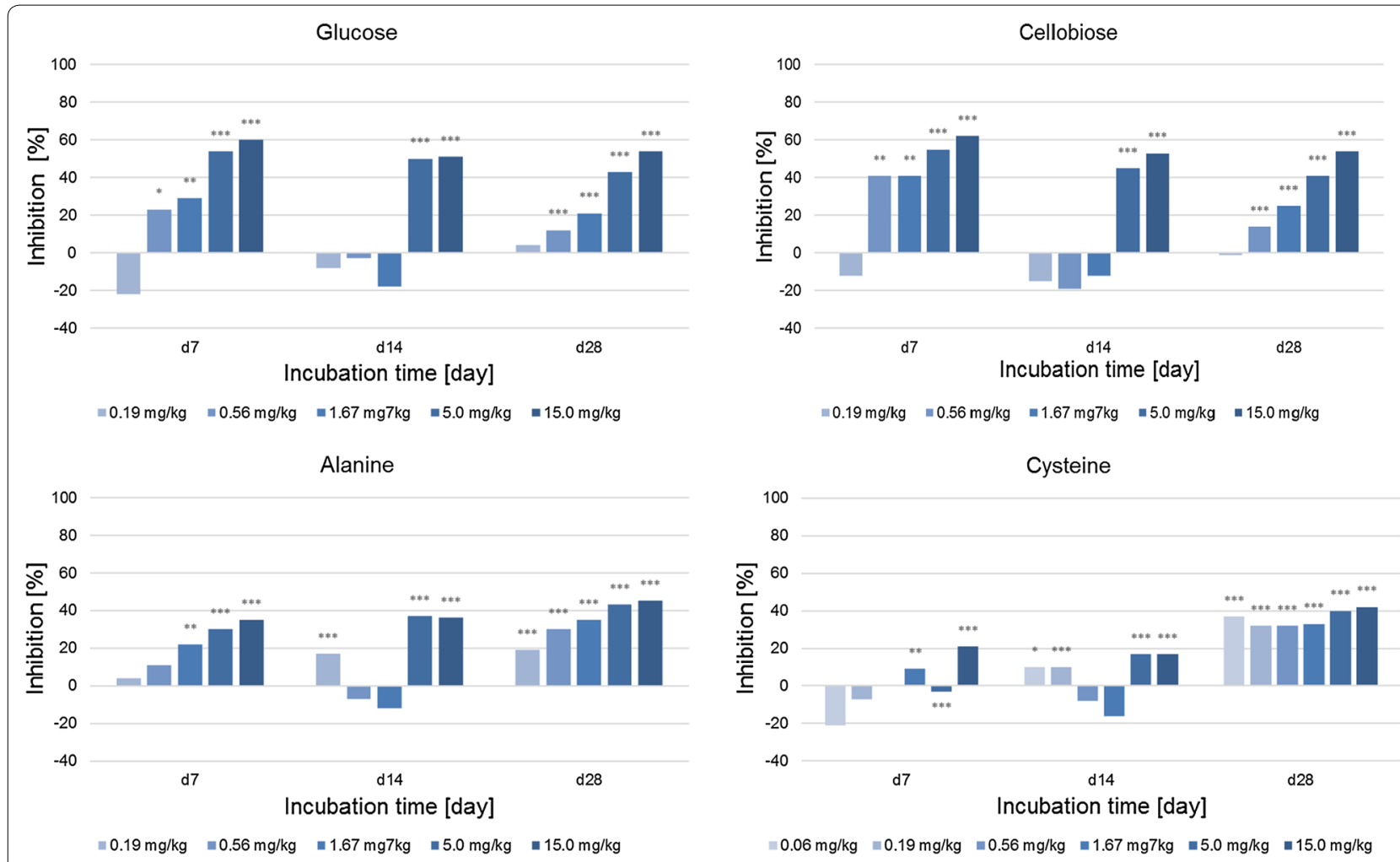

Fig. 2 Effect of the silver nanomaterial NM-300K on substrate-induced respiration activity. Statistical significance $(a=0.05)$ is indicated on the bars representing inhibition: $0.01 \leq p<0.05 ;{ }^{* *} 0.001 \leq p<0.01 ;{ }^{* * *} p<0.001$

Table $2 \mathrm{EC}_{10}$ and $\mathrm{EC}_{50}$ values [mg/kg] of the silver nanomaterial NM-300K for the inhibition of substrate-induced respiration activity

\begin{tabular}{|c|c|c|c|c|c|c|c|c|}
\hline \multirow[t]{2}{*}{ Day } & \multicolumn{2}{|l|}{ Glucose } & \multicolumn{2}{|l|}{ Cellobiose } & \multicolumn{2}{|l|}{ L-Alanine } & \multicolumn{2}{|c|}{ Cysteine } \\
\hline & $\mathrm{EC}_{10}{ }^{\mathrm{a}}$ & $\mathrm{EC}_{50}{ }^{\mathrm{a}}$ & $\mathrm{EC}_{10}{ }^{\mathrm{a}}$ & $\mathrm{EC}_{50}{ }^{\mathrm{a}}$ & $\mathrm{EC}_{10}{ }^{\mathrm{a}}$ & $\overline{E C_{50}{ }^{a}}$ & $\mathrm{EC}_{10}{ }^{\mathrm{a}}$ & $\mathrm{EC}_{50^{\circ}}{ }^{\mathrm{a}}$ \\
\hline 7 & $0.31[0.07-1.51]$ & 4.92 [2.43-9.97] & $0.12[0.01-1.64]$ & $3.61[1.13-11.53]$ & $0.30[0.01-11.42]$ & $n d^{b}$ & nd & nd \\
\hline 14 & $1.69[0.63-4.53]$ & $9.46[6.25-14.31]$ & $0.12[0.01-1.59]$ & 3.63 [1.15-11.50] & 2.71 [0.69-10.63] & nd & nd & nd \\
\hline 28 & $0.42[0.24-0.76]$ & 10.28 [8.06-13.10] & $0.40[0.07-0.88]$ & 10.04 [6.09-23.09] & nd & nd & nd & nd \\
\hline
\end{tabular}

a Values in brackets indicate $95 \%$ confidence limit

${ }^{\mathrm{b}} \mathrm{nd}$, not determinable due to data quality or not plausible (e.g., considerably outside the range of test concentrations)

Steinhaus similarity index (based on absolute values) and the Stander similarity index (based on normalized values) both indicated slight differences from the controls at the two highest test concentrations (Fig. 5). However, we observed no differences in the Shannon index or evenness as indicators of diversity (Additional file 1: Figure S1).

\section{Discussion}

\section{Overview}

To address the recommendations published in a recent EFSA scientific opinion document [1], we compared the sensitivity of three tests for microbial activity in response to the effects caused by a model silver nanomaterial, NM-300K. We compared the PAO, MicroResp and exoenzyme tests for microbial functions, as well as the NGSbased analysis of bacterial genomic diversity. Although the EFSA document refers specifically to pesticides, current efforts to harmonize regulatory guidelines indicate that the same recommendations may, in the future, be applied to the risk assessment and regulation of other kinds of chemicals, including silver nanomaterials. The assessment of microbial test results in the context of substance regulation differs according to the nature of the 

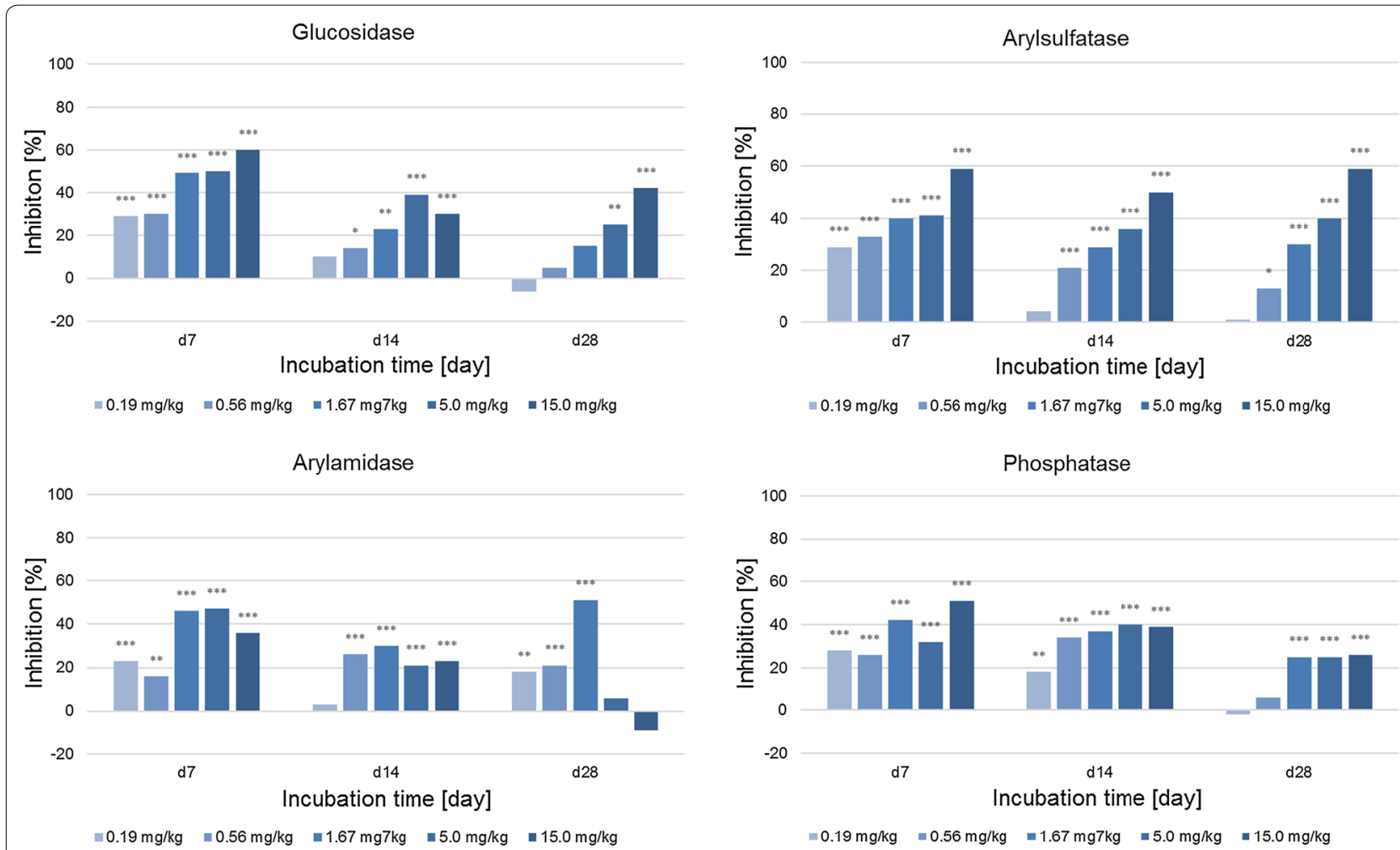

Fig. 3 Effect of the silver nanomaterial NM-300K on microbial exoenzyme activity. Statistical significance $(a=0.05)$ is indicated on the bars representing inhibition: ${ }^{*} 0.01 \leq p<0.05 ;{ }^{* *} 0.001 \leq p<0.01 ;{ }^{* * *} p<0.001$

Table $3 \mathrm{EC}_{10}$ and $\mathrm{EC}_{50}$ values $[\mathrm{mg} / \mathrm{kg}$ ] of the silver nanomaterial NM-300K for the inhibition of the enzymes glucosidase and arylsulfatase

\begin{tabular}{|c|c|c|c|c|}
\hline \multirow[t]{2}{*}{ Day } & \multicolumn{2}{|l|}{ Glucosidase } & \multicolumn{2}{|l|}{ Arylsulfatase } \\
\hline & $\mathrm{EC}_{10}[\mathrm{mg} / \mathrm{kg}]^{\mathrm{a}}$ & $E C_{50}[\mathrm{mg} / \mathrm{kg}]^{\mathrm{a}}$ & $\mathrm{EC}_{10}[\mathrm{mg} / \mathrm{kg}]^{\mathrm{a}}$ & $\mathrm{EC}_{50}[\mathrm{mg} / \mathrm{kg}]^{\mathrm{a}}$ \\
\hline 7 & $n d^{b}$ & $\begin{array}{c}2.02[0.15- \\
26.92]\end{array}$ & nd & $\begin{array}{c}7.01[2.30- \\
21.36]\end{array}$ \\
\hline 14 & nd & nd & $\begin{array}{l}0.19[0.01- \\
0.58]\end{array}$ & $\begin{array}{c}14.46[6.82- \\
81.19]\end{array}$ \\
\hline 28 & 1.07 [0.11-9.90] & $\begin{array}{c}22.29[8.18- \\
60.70]\end{array}$ & $\begin{array}{l}0.31[0.00- \\
1.02]\end{array}$ & $\begin{array}{c}8.86[3.97- \\
67.01]\end{array}$ \\
\hline
\end{tabular}

a Values in brackets indicate $95 \%$ confidence limit

b nd, not determinable due to data quality or not plausible (e.g., considerably outside the range of test concentrations)

test substance. If agrochemicals are tested, the effects in treated and control samples are compared with a threshold value of $25 \%$ [40]. For other substances, endpoints such as EC values are calculated [8, 12, 41]. Concentration-effect tests are also recommended for agrochemicals to determine the magnitude and temporal scale of their effects [1].

\section{The PAO test}

The PAO test focuses on a small group of specialized microorganisms with low diversity. We observed statistically significant differences between control and test samples at NM-300K concentrations $\geq 1.67 \mathrm{mg} / \mathrm{kg}$, with a slightly increasing effect over time. These results, and the corresponding EC values, are in agreement with our previous studies, confirming the reproducibility of the PAO test [42-44]. Despite the advantages of the PAO test, OECD Guideline [8] sets out a different procedure to be used for the registration or approval of substances. This involves the mixing of spiked soil samples with a complex nitrogen source, and as well as nitrification it also detects the degradation of organic carbon sources. The inorganic ammonium, nitrite and nitrate concentrations used as endpoints therefore reflect the activity of a diverse microbial population and multiple microbial transformations. Accordingly, the PAO test is suitable as a specific indicator for toxicity whereas the nitrogen transformation method described in OECD Guideline 2016 provides more general information on the microbial population and nutrient cycles in the soil, at the expense of assay sensitivity. The PAO test is also more generally applicable, being suitable not only for testing organic compounds but also ion-releasing 


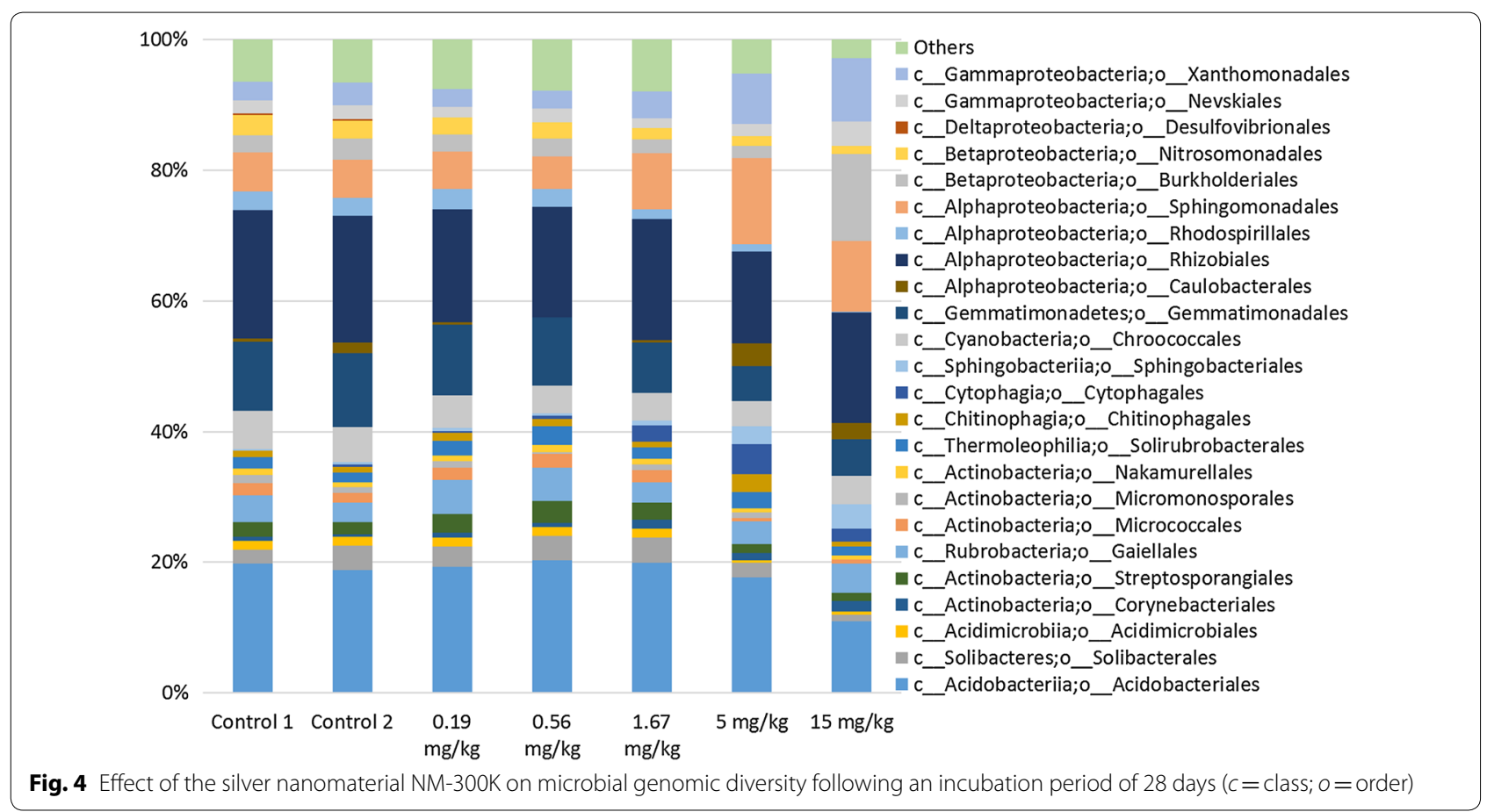

Table 4 Effect of the silver nanomaterial NM-300K on bacterial orders, marked according to the fold-difference from the mean value of the two normalized controls (decreases are indicated in red and yellow, and increases in blue)

\begin{tabular}{ll|l|l|l|l|l|}
$<0.01$ & $<0.1$ & $<0.5$ & $0.5-2$ & $>2$ & $>10$
\end{tabular}

\begin{tabular}{|c|c|c|c|c|c|c|c|c|c|}
\hline Taxon-class & Taxon-order & Control N ${ }^{a}$ & Control 1 & Control 2 & $0.19 \mathrm{mg} / \mathrm{kg}$ & $0.56 \mathrm{mg} / \mathrm{kg}$ & $1.67 \mathrm{mg} / \mathrm{kg}$ & $5 \mathrm{mg} / \mathrm{kg}$ & $15 \mathrm{mg} / \mathrm{kg}$ \\
\hline Deltaproteobacteria & Desulfovibrionales & 72.5 & 0.99 & 1.01 & 0.00 & 0.00 & 0.00 & 0.00 & 0.00 \\
\hline Actinobacteria & Propionibacteriales & 159.5 & 0.95 & 1.05 & 0.82 & 0.48 & 0.43 & 0.00 & 0.00 \\
\hline Actinobacteria & Micromonosporales & 281.5 & 1.19 & 0.81 & 0.78 & 0.19 & 0.87 & 1.14 & 0.00 \\
\hline Alphaproteobacteria & Rhodospirillales & 769.0 & 1.00 & 1.00 & 0.91 & 0.73 & 0.55 & 0.50 & 0.01 \\
\hline Solibacteres & Solibacterales & 786.5 & 0.71 & 1.29 & 0.88 & 1.00 & 1.36 & 1.05 & 0.37 \\
\hline Actinobacteria & Micrococcales & 456.0 & 1.09 & 0.91 & 0.92 & 1.00 & 1.18 & 0.42 & 0.38 \\
\hline Acidimicrobiia & Acidimicrobiales & 402.5 & 0.98 & 1.02 & 0.75 & 0.72 & 0.97 & 0.30 & 0.38 \\
\hline Others & Others & 1805.0 & 0.98 & 1.02 & 0.94 & 0.92 & 1.22 & 1.08 & 0.46 \\
\hline Betaproteobacteria & Nitrosomonadales & 814.0 & 1.05 & 0.95 & 0.69 & 0.65 & 0.59 & 0.64 & 0.47 \\
\hline Gemmatimonadetes & Gemmatimonadales & 3017.0 & 0.95 & 1.05 & 0.81 & 0.73 & 0.71 & 0.65 & 0.54 \\
\hline Acidobacteriia & Acidobacteriales & 5347.5 & 1.01 & 0.99 & 0.81 & 0.80 & 1.04 & 1.22 & 0.60 \\
\hline Actinobacteria & Streptosporangiales & 565.0 & 1.07 & 0.93 & 1.13 & 1.27 & 1.27 & 0.92 & 0.62 \\
\hline Actinobacteria & Nakamurellales & 243.0 & 1.06 & 0.94 & 0.82 & 1.00 & 1.01 & 1.00 & 0.77 \\
\hline Cyanobacteria & Chroococcales & 1539.0 & 1.03 & 0.97 & 0.72 & 0.59 & 0.78 & 0.91 & 0.83 \\
\hline Thermoleophilia & Solirubrobacterales & 442.0 & 1.08 & 0.92 & 1.12 & 1.37 & 1.04 & 2.05 & 0.84 \\
\hline Alphaproteobacteria & Rhizobiales & 5391.5 & 0.99 & 1.01 & 0.72 & 0.67 & 0.96 & 0.96 & 0.93 \\
\hline Chitinophagia & Chitinophagales & 266.5 & 1.05 & 0.95 & 1.05 & 0.83 & 0.99 & 3.74 & 0.94 \\
\hline Rubrobacteria & Gaiellales & 982.5 & 1.14 & 0.86 & 1.20 & 1.10 & 0.88 & 1.27 & 1.36 \\
\hline Gammaproteobacter & Nevskiales & 576.5 & 0.94 & 1.06 & 0.66 & 0.79 & 0.70 & 1.23 & 1.91 \\
\hline Alphaproteobacteria & Sphingomonadales & 1654.5 & 1.00 & 1.00 & 0.77 & 0.64 & 1.44 & 2.95 & 1.91 \\
\hline Alphaproteobacteria & Caulobacterales & 292.0 & 0.39 & 1.61 & 0.25 & 0.00 & 0.30 & 4.34 & 2.49 \\
\hline Gammaproteobacter & Xanthomonadales & 880.5 & 0.88 & 1.12 & 0.70 & 0.66 & 1.31 & 3.18 & 3.23 \\
\hline Actinobacteria & Corynebacteriales & 137.5 & 1.24 & 0.76 & 1.32 & 0.88 & 2.66 & 3.16 & 3.53 \\
\hline Betaproteobacteria & Burkholderiales & 781.0 & 0.87 & 1.13 & 0.76 & 0.73 & 0.77 & 0.87 & 5.00 \\
\hline Cytophagia & Cytophagales & 53.5 & 0.00 & 2.00 & 1.25 & 1.93 & 12.88 & 31.51 & 10.65 \\
\hline Sphingobacteriia & Sphingobacteriales & 93.0 & 0.85 & 1.15 & 1.18 & 0.87 & 2.12 & 11.04 & 11.69 \\
\hline
\end{tabular}

a Mean value of the total abundance in the two controls 
Table $5 \mathrm{EC}_{10}$ and $\mathrm{EC}_{50}$ values $[\mathrm{mg} / \mathrm{kg}$ ] of the silver nanomaterial NM-300K for different bacterial orders

\begin{tabular}{|c|c|c|c|}
\hline Taxon-class & Taxon-order & $\mathrm{EC} 10[\mathrm{mg} / \mathrm{kg}]^{\mathrm{a}}$ & $\mathrm{EC} 50[\mathrm{mg} / \mathrm{kg}]^{\mathrm{a}}$ \\
\hline Acti & $\begin{array}{l}\text { Propionibacte- } \\
\text { riales }\end{array}$ & & 7] \\
\hline $\begin{array}{l}\text { Alphaproteobac- } \\
\text { teria }\end{array}$ & Rhodospirillales & $-1042]$ & 2.42 [0.84-6.97] \\
\hline $\begin{array}{l}\text { Gemmatimona- } \\
\text { detes }\end{array}$ & $\begin{array}{l}\text { Gemmatimo- } \\
\text { nadales }\end{array}$ & $-0.63]$ & 19.5 [00.9-nd] \\
\hline
\end{tabular}

a Values in brackets indicate $95 \%$ confidence limit

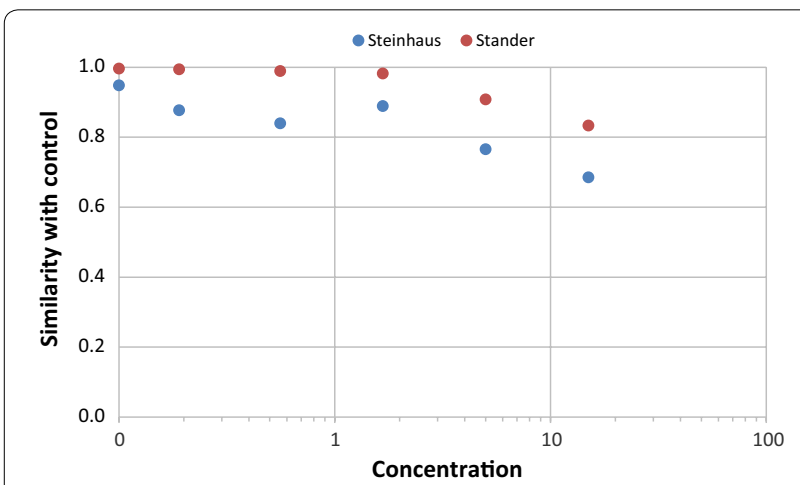

Fig. 5 Steinhaus and Stander similarity indices [39] for the taxonomic distribution of bacteria in control samples and samples treated with different concentrations of the silver nanomaterial NM-300K

substances, whose toxicity is underestimated when the soil contains significant quantities of organic matter because the latter adsorbs ions and therefore reduces their bioavailability [26].

\section{Substrate-induced respiration test}

The $\mathrm{EC}_{10}$ and $\mathrm{EC}_{50}$ values in the MicroResp system revealed that substrate-induced respiration is less sensitive than PAO activity when testing for the effects of silver nanomaterials, and the difference between the two methods increased over time. The PAO test showed an increase in toxicity with longer incubation periods, reflecting the continued detrimental effects of exposure to NM-300K among the specialized microbes capable of PAO activity. In contrast, glucose-induced respiration showed a decline in toxicity over time, reflecting widespread functional redundancy for this process within the microbial community. Species that are less sensitive to NM-300K are likely to metabolize glucose, and their proliferation would lead to the recovery of microbial respiration.

One of the drawbacks of the MicroResp system is the 6-h interval between measurements. According to OECD Guideline [12], the respiration rate should be measured continuously or at hourly/two-hourly intervals for 12 consecutive hours in order to calculate a mean rate. Furthermore, ISO 17155 [45] states that respiration rates used to calculate the mean must be near constant, thus excluding the lag phase and exponential growth phase. The MicroResp system measures the amount of $\mathrm{CO}_{2}$ produced at the test start and endpoint. There is no information about the constancy of respiration in the interim period of $6 \mathrm{~h}$. For example, heavy metals can increase the lag time prior to the mineralization of amino acids [46]. If a fixed incubation period is used, an extended lag time results in higher toxicity compared to evaluations where only the linear part of the respiration curve is considered. We therefore recommend that results obtained with the MicroResp system are compared with those obtained from tests with additional measurements and more frequent testing intervals.

When cysteine was used as the substrate, the inhibition of respiration remained constant on day 28 regardless of the NM-300K concentration, whereas the other substrates showed concentration-dependent effects. Campbell et al. [47] described positive color reactions when cysteine was used as a substrate, which may make it unsuitable, but we found no evidence for positive color reactions after 7 and 14 days, in agreement with Wakelin et al. [48].

The miniaturized MicroResp format may also affect the results. The PAO test uses soil samples of $25 \mathrm{~g}$, which generated better concentration-effect relationships than the MicroResp and exoenzyme tests, both of which are carried out in multiwell plates with small soil samples. We were able to calculate EC values with confidence intervals at all sampling points in the PAO test but not in the others, and the small sample size may contribute to this issue.

Metabolic profiles based on complementary carbon sources can provide rich information about functional microbial diversity in soil samples, and can be used for the characterization of soils and the effects of contamination [49-51]. The EFSA opinion paper does not recommend the use of any specific carbon sources, and a standard test set covering different metabolic pathways remains to be defined. The selection of carbon sources must be considered carefully because this determines the discriminatory power and ecological relevance of the respiration profiles [52]. Our results indicate that glucose and cellobiose are equivalent and it is unnecessary to use both. The selection of additional carbon sources addressing further metabolic transformations should be based on environmental relevance, such as carboxylic acids, alcohols, fatty acids, polymers, aromatic structures and aliphatic compounds. The substances should be bioavailable (and therefore preferably soluble in water) due to the 
short incubation time of the test. Creamer et al. [53] used a set of seven substances comprising $\mathrm{D}-(+)$-galactose, L-malic acid, $\gamma$-aminobutyric acid, $N$-acetylglucosamine, D- $(+)$-glucose, $\alpha$-ketoglutarate, citric acid and water for basal respiration measurements. This was selected from among the 15 substances used by Campbell et al. [9], which included further sugars, amino acids, dicarboxylic acids and the aromatic compound protocatechuic acid, representing diverse carbon sources reported as constituents of root exudates and suitable for the discrimination of soils [47]. Linolenic acid, malic acid, oleic acid, arginine, serine, lactic acid, oxalic acid, trehalose, stearic acid and $\beta$-methyl $\mathrm{D}$-glucoside were identified as the $10 \mathrm{car}$ bon sources with the highest power to distinguish among different sites [47].

\section{Exoenzyme activity test}

In the exoenzyme activity test with four enzymes, $\beta$-glucosidase and arylsulfatase showed concentrationeffect relationships at the three measuring time points. The EC values for $\beta$-glucosidase indicated that the sensitivity of the test was similar the substrate-induced respiration test with glucose or cellobiose. Arylsulfatase had no direct counterpart among the substrates used in the respiration test, but the sensitivity was comparable to $\beta$-glucosidase. Dick et al. [54] reported that the application of ammonium-based nitrogen fertilizer inhibited soil amidase activity, indicating a specific feedback mechanism, whereas no correlation was observed for $\beta$-glucosidase or arylsulfatase. It is unclear whether the different profiles of $\beta$-glucosidase and arylsulfatase versus arylamidase activity in our test also indicate different effects of NM-300K and corresponding feedback mechanisms. Based on the investigation of eight exoenzymes involved in various transformation steps (acid phosphatase, arylsulfatase, catalase, dehydrogenase, fluorescein diacetate hydrolase, protease, urease, and $\beta$-glucosidase), Chae et al. [55] recommended $\beta$-glucosidase for the measurement of soil ecosystem health. The different temporal profiles of three enzymes (leucine aminopeptidase, phosphatase, and $\beta$-glucosidase) in the presence of metals during an incubation period of 21 days [56] and of four enzymes (acid phosphatase, arylsulfatase, fluorescein diacetate hydrolase, and urease) affected by fluorine [57] indicate that more than one enzyme is required for risk assessment applications.

\section{Analysis of genomic diversity by NGS}

Functional assays provide information about microbial activity under the test conditions, whereas NGS provides information about the diversity of cultivable and non-cultivable microorganisms and can reveal changes in population structure that are not detected by activity assays due to community-level metabolic redundancy [58] or changes in the microbial community that occur during the functional assay [59]. The link between genomic and functional diversity, or between species richness and ecosystem services, has been widely discussed [4,60]. We found that NM-300K caused a shift in the microbial community, enriching the soil for microbial groups representing the Proteobacteria (Caulobacterales, Burkholderiales, and Xanthomonadales), Cytophagales and Sphingobacteriales. Sphingobacteria and Proteobacteria are often found in soils contaminated with polyaromatic hydrocarbons [61]. Although the ability to degrade such compounds was not investigated in this study because the model contaminant was a metal, the enrichment of these microbial groups may indicate a disturbance in the microbial population resulting in the proliferation of organisms insensitive to the test compound. The depletion of particular microbial groups can slow down the transformation functions they normally provide. In this study, we observed a link between the depletion of Nitrosomonadales and the reduced PAO activity, whereas for the other bacterial orders there was no one-on-one relationship to specific functions. As stated by EFSA [1], functional redundancy should contribute less to insensitivity when studying more specialized functions.

The analysis of genomic DNA reveals the presence of bacteria without providing information about their activity, and extracellular DNA that persists in the soil may also be detected [62]. We found that our functional tests and genomic diversity analysis achieved comparable sensitivity in detecting the effects of NM-300K on soil microbes. The concentrations of NM-300K that affected microbial activity in the test systems also triggered clear changes in the composition of the microbial community. Significant effects at an NM-300K concentration of at least $1.67 \mathrm{mg} / \mathrm{kg}$ were observed in all four tests. The $\mathrm{EC}_{50}$ values calculated for the genomic survey were also comparable to those observed in the functional tests. Similar results were reported for the metagenomic and functional impact on soil microorganisms of a $\mathrm{Cu}(\mathrm{OH})_{2}$ nanopesticide [63] and four frequently used organic herbicides tested at a concentration corresponding to the upper recommended rate [64]. None of the herbicides affected the microbial richness or evenness, or the composition of the bacterial and archaeal communities, and from the functional perspective there was no significant effect on enzyme activities or the ability to degrade 15 substrates. The only exception was a short-term effect on the ability of soil microorganisms to utilize three organic acids and one amino acid. However, studies indicating no effects are of limited use when comparing the sensitivity 
of different test methods. Diversity indices such as the Shannon index and species evenness are often used to measure the impact of a test substance on whole communities, providing information on changes in species richness and taxonomic distribution [39]. However, samples with the same index can feature different communities. Such changes can be demonstrated by similarity indices, which measure the degree of equality or difference in the community [39]. Our study showed that NM-300K did not affect the overall diversity of the community because there was no change in the Shannon index or species evenness. However, changes became visible when calculating similarity indices, showing that NM-300K does not reduce diversity per se, but modifies the composition of the diverse microbial community in the soil.

\section{Conclusion}

In our study we compared the sensitivity of four tests for their ability to detect the effects of a model silver nanomaterial on soil microorganisms. We based our selection on EFSA recommendations to (i) evaluate the MicroResp system and (ii) consider diverse microbial processes as well as structural diversity [1]. We therefore evaluated the MicroResp substrate-induced respiration test system and exoenzyme test with four substrates each, as well as the PAO test for nitrogen transformation. We found that the sensitivity of all three functional tests was comparable for the model silver nanomaterial. However, several issues remain to be addressed before we can decide on the suitability of these approaches for the registration or approval of substances. For example, the tests should be evaluated with a broader range of model substances, including non-ionic compounds. This will indicate whether different substrates or different taxonomic levels influence the discriminatory power of the tests. Finally, the amount of soil in each replicate appears to influence the validity of the observed concentration-effect relationships, and this particular aspect must be investigated in more detail.

\section{Supplementary information}

Supplementary information accompanies this paper at https://doi. org/10.1186/s12302-019-0268-z.

Additional file 1. Additional tables and figure.

\section{Abbreviations}

ECx: effect concentration with $x \%$ effect (e.g., 10\%, 50\%); ECHA: European Chemical Agency; EFSA: European Food Safety Authority; NGS: next-generation sequencing; NM: nanomaterial; PAO: potential ammonium oxidation activity; $\mathrm{WHC}_{\text {max }}$ : maximum water holding capacity.

\section{Acknowledgements}

The authors would like to thank Udo Hommen for support in the evaluation of the genomic data, Sebastian Eilebrecht for discussion and description of the microbiome profiling approach and Dr. Richard M. Twyman for reviewing the manuscript.

\section{Authors' contributions}

$\mathrm{KHR}$ designed the work and interpreted the data. AH and RS performed the experiments, and evaluated the data, focusing on functional diversity; FW led the experimental work in the molecular biology laboratory and evaluated the data, focusing on genomic diversity. The manuscript was written by KHR and GB. All authors read and approved the final manuscript.

\section{Funding}

This project has received funding from the European Union's Horizon 2020 research and innovation programme under Grant Agreement No. 760928.

\section{Availability of data and materials}

All data generated during this study are included in this published article and its additional file.

Ethics approval and consent to participate

Not applicable.

\section{Consent for publication}

Not applicable.

\section{Competing interests}

The authors declare that they have no competing interests.

\section{Author details}

${ }^{1}$ Fraunhofer Institute for Molecular Biology and Applied Ecology IME, Auf dem Aberg 1, 57392 Schmallenberg, Germany. ${ }^{2}$ Institute of Geography, Osnabrück University, Osnabrück, Germany.

Received: 6 March 2019 Accepted: 19 October 2019

Published online: 06 November 2019

\section{References}

1. EFSA_PPR_Panel, Ockleford C, Adriaanse P, Berny P, Brock T, Duquesne S, Grilli S, Hernandez-Jerez AF, Bennekou SH, Klein M, Kuhl T, Laskowski R, Machera K, Pelkonen O, Pieper S, Stemmer M, Sundh I, Teodorovic I, Tiktak A, Topping CJ, Wolterink G, Craig P, Jong FD, Manachini B, Sousa P, Swarowsky K, Auteri D, Arena M, Smith R (2017) Scientific opinion addressing the state of the science on risk assessment of plant protection products for in soil organisms. EFSA J 15(2):4690. https://doi. org/10.2903/j.efsa.2017.4690

2. Schäfer RB, Liess M, Altenburger R, Filser J, Hollert H, Roß-Nickoll M, Schäffer A, Scheringer M (2019) Future pesticide risk assessment: narrowing the gap between intention and reality. Environ Sci Eur 31(1):21. https ://doi.org/10.1186/s12302-019-0203-3

3. Wong JWY, Hitzfeld B, Zimmermann M, Werner I, Ferrari BJD (2018) Current developments in soil ecotoxicology and the need for strengthening soil ecotoxicology in Europe: results of a stakeholder workshop. Environ Sci Eur 30(1):49. https://doi.org/10.1186/s12302-018-0180-y

4. Singh BK, Quince C, Macdonald CA, Khachane A, Thomas N, Al-Soud WA, Sørensen SJ, He Z, White D, Sinclair A, Crooks B, Zhou J, Campbell CD (2014) Loss of microbial diversity in soils is coincident with reductions in some specialized functions. Environ Microbiol 16(8):2408-2420. https:// doi.org/10.1111/1462-2920.12353

5. ECHA (2013) Guidance on information requirements - Guidance on regulation (EU) No 528/2012 concerning the making available on the market and use of biocidal products (BPR). https://echa.europa.eu/docum ents/10162/23492134/guidance_on_information_requirements_bpr_ part_a_v10_superseded_en.pdf/acf41ad5-420e-c005-4485-dce779c897 a9

6. ECHA (2017) Guidance for the implementation of REACH-Guidance on information requirements and chemical safety assessment. 
Chapter R.7c: Endpoint specific guidance. http://echaeuropaeu/ documents/10162/13632/information_requirements_r7c_en.pdf

7. European Commission (2013) Commission Communication in the framework of the implementation of Commission Regulation (EU) No 283/2013 of 1 March 2013 setting out the data requirements for active substances, in accordance with Regulation (EC) No 1107/2009 of the European Parliament and of the Council concerning the placing of plant protection products on the market (2013/C 95/01). Official Journal of the European Commission. https://www.google.com/ url? sa $=t \& r c t=j \& q=\&$ es $r c=s \&$ source $=$ web\& $c d=1 \& c a d=r j a \& u a c t=8 \& v e$ $\mathrm{d}=$ 2ahUKEwii4M3R47DfAhVysXEKHTsHCloQFjAAegQICRAC\&url=https \%3A\%2F\%2Feur-lex.europa.eu\%2FLexUriServ\%2FLexUriServ.do\%3Furi \%3DOJ\%3AC\%3A2013\%3A095\%3A0001\%3A0020\%3AEN\%3APDF \&usg=AOVVaw1RRWU6pDEOdbyHIUKW2O_Y

8. OECD Guideline 216 (2000) OECD Guideline for the testing of chemicals. Test No. 216: Soil Microorganisms: Nitrogen Transformation Test. Organisation for Economic Co-operation and Development, Paris

9. Campbell CD, Chapman SJ, Cameron CM, Davidson MS, Potts JM (2003) A rapid microtiter plate method to measure carbon dioxide evolved from carbon substrate amendments so as to determine the physiological profiles of soil microbial communities by using whole soil. Appl Environ Microbiol 69(6):3593-3599. https://doi.org/10.1128/ aem.69.6.3593-3599.2003

10. Wakelin S, Lombi E, Donner E, MacDonald L, Black A, Callaghan MO (2013) Application of MicroResp for soil ecotoxicology. Environ Pollut 179:177-184

11. Rowell $\mathrm{MJ}$ (1995) Colorimetric method for $\mathrm{CO}_{2}$ measurement in soils. Soil Biol Biochem 27(3):373-375. https://doi.org/10.1016/0038-0717(94)00218 $-P$

12. OECD Guideline 217 (2000) OECD Guideline for the Testing of Chemicals. Test Guideline 217: Soil Microorganisms: Carbon Transformation Test. Organisation for Economic Co-operation and Development, Paris

13. ISO 20130 (2018) Soil quality —-measurement of enzyme activity patterns in soil samples using colorimetric substrates in micro-well plates. International Organization for Standardization, Genf

14. ISO/TS Guideline 22939 (2010) Soil quality — measurement of enzyme activity patterns in soil samples using fluorogenic substrates in microwell plates. International Organization for Standardization, Genf

15. Kandeler E (2015) Physiological and biochemical methods for studying soil biota and their functions. In: Paul EA (ed) Soil microbiology, ecology, and biochemistry, 4th edn. Elsevier, Fort Collings, pp 53-83

16. Allison SD (2006) Soil minerals and humic acids alter enzyme stability: implications for ecosystem processes. Biogeochemistry 81(3):361-373. https://doi.org/10.1007/s10533-006-9046-2

17. Blankinship JC, Becerra CA, Schaeffer SM, Schimel JP (2014) Separating cellular metabolism from exoenzyme activity in soil organic matter decomposition. Soil Biol Biochem 71:68-75. https://doi.org/10.1016/j. soilbio.2014.01.010

18. Creamer RE, Bellamy P, Black HIJ, Cameron CM, Campbell CD, Chamberlain P, Harris J, Parekh N, Pawlett M, Poskitt J, Stone D, Ritz K (2009) An inter-laboratory comparison of multi-enzyme and multiple substrateinduced respiration assays to assess method consistency in soil monitoring. Biol Fertil Soils 45(6):623-633. https://doi.org/10.1007/s0037 4-009-0374-y

19. Dick RP, Dick LK, Deng S, Li X, Kandeler E, Poll C, Freeman C, Jones TG, Weintraub MN, Esseili KA, Saxena J (2018) Cross-laboratory comparison of fluorimetric microplate and colorimetric bench-scale soil enzyme assays. Soil Biol Biochem 121:240-248. https://doi.org/10.1016/j.soilb io.2017.12.020

20. Samarajeewa AD, Velicogna JR, Princz Jl, Subasinghe RM, Scroggins RP, Beaudette LA (2017) Effect of silver nano-particles on soil microbial growth, activity and community diversity in a sandy loam soil. Environ Pollut 220:504-513. https://doi.org/10.1016/j.envpol.2016.09.094

21. Zhang S, Liu X, Jiang Q, Shen G, Ding W (2017) Legacy effects of continuous chloropicrin-fumigation for 3-years on soil microbial community composition and metabolic activity. AMB Express 7(1):178. https://doi. org/10.1186/s13568-017-0475-1

22. Zhang Y, Cong J, Lu H, Li G, Qu Y, Su X, Zhou J, Li D (2014) Community structure and elevational diversity patterns of soil acidobacteria. J Environ Sci 26(8):1717-1724. https://doi.org/10.1016/j.jes.2014.06.012
23. Bowles TM, Acosta-Martínez V, Calderón F, Jackson LE (2014) Soil enzyme activities, microbial communities, and carbon and nitrogen availability in organic agroecosystems across an intensively-managed agricultural landscape. Soil Biol Biochem 68:252-262. https://doi.org/10.1016/j.soilb io.2013.10.004

24. Torsvik V, Øvreås L (2002) Microbial diversity and function in soil: from genes to ecosystems. Curr Opin Microbiol 5(3):240-245. https://doi. org/10.1016/S1369-5274(02)00324-7

25. ISO 15685 (2012) Soil quality - determination of potential nitrification and inhibition of nitrification — rapid test by ammonium oxidation. International Organization for Standardization, Genf

26. Hund-Rinke K, Schlich K (2014) The potential benefits and limitations of different test procedures to determine the effects of Ag nanomaterials and $\mathrm{AgNO} 3$ on microbial nitrogen transformation in soil. Environ Sci Eur 26(1):28. https://doi.org/10.1186/s12302-014-0028-z

27. Bundschuh M, Filser J, Lüderwald S, McKee MS, Metreveli G, Schaumann GE, Schulz R, Wagner S (2018) Nanoparticles in the environment: where do we come from, where do we go to? Environ Sci Eur 30(1):6. https:// doi.org/10.1186/s12302-018-0132-6

28. Anand R, Bhagat M (2019) Silver nanoparticles (AgNPs): as nanopesticides and nanofertilizers. MOJ Biol Med 4:19-20

29. Roseline TA, Murugan M, Sudhakar MP, Arunkumar K (2019) Nanopesticidal potential of silver nanocomposites synthesized from the aqueous extracts of red seaweeds. Environ Technol Innovat 13:82-93. https://doi. org/10.1016/j.eti.2018.10.005

30. Rouhani M, Samih MA, Kalantari S (2012) Insecticide effect of silver and zinc nanoparticles against Aphis nerii boyer de fonscolombe (hemiptera: Aphididae). Chilean J Agric Res 72:590-594

31. OECD (2007) Safety of manufactured nanomaterials - Sponsorship Programme for the Testing of Manufactured Nanomaterials. http://www. oecd.org/science/nanosafety/sponsorshipprogrammeforthetestingof manufacturednanomaterials.htm

32. Klein CL, Comero S, Stahlmecke B, Romazanov J, Kuhlbusch TAJ, Doren EV, Temmerman P-JD, Maat J, Wick P, Krug H, Locoro G, Hund-Rinke K, Kördel W, Friedrichs S, Maler G, Werner J, Lingsinger T, Gawlik BM (2011) NM-series of representative manufactured nanomaterials NM-300 silver characterisation, stability, homogeneity. JRC Sci Tech Rep. https://doi. org/10.2788/23079

33. Turner S, Pryer KM, Miao VPW, Palmer JD (1999) Investigating deep phylogenetic relationships among cyanobacteria and plastids by small subunit rRNA sequence analysis. J Eukaryot Microbiol 46(4):327-338. https://doi. org/10.1111/j.1550-7408.1999.tb04612.x

34. Kisand V, Cuadros R, Wikner J (2002) Phylogeny of culturable estuarine bacteria catabolizing riverine organic matter in the northern Baltic Sea. Appl Environ Microbiol 68(1):379-388. https://doi.org/10.1128/ aem.68.1.379-388.2002

35. Edgar RC, Haas BJ, Clemente JC, Quince C, Knight R (2011) UCHIME improves sensitivity and speed of chimera detection. Bioinformatics 27(16):2194-2200. https://doi.org/10.1093/bioinformatics/btr381

36. Eren AM, Maignien L, Sul WJ, Murphy LG, Grim SL, Morrison HG, Sogin ML (2013) Oligotyping: differentiating between closely related microbial taxa using 16S rRNA gene data. Methods Ecol Evol 4(12):1111-1119. https:// doiorg/10.1111/2041-210X12114

37. Eren AM, Morrison HG, Lescault PJ, Reveillaud J, Vineis JH, Sogin ML (2015) Minimum entropy decomposition: unsupervised oligotyping for sensitive partitioning of high-throughput marker gene sequences. ISME J 9(4):968-979. https://doi.org/10.1038/ismej.2014.195

38. Caporaso JG, Kuczynski J, Stombaugh J, Bittinger K, Bushman FD, Costello EK, Fierer N, Peña AG, Goodrich JK, Gordon Jl, Huttley GA, Kelley ST, Knights D, Koenig JE, Ley RE, Lozupone CA, McDonald D, Muegge BD, Pirrung M, Reeder J, Sevinsky JR, Turnbaugh PJ, Walters WA, Widmann J, Yatsunenko T, Zaneveld J, Knight R (2010) QIIME allows analysis of highthroughput community sequencing data. Nat Methods 7(5):335-336. https://doi.org/10.1038/nmeth.f.303

39. Hommen U, Veith D, Dülmer U (1994) A computer program to evaluate plankton data from freshwater field tests. In: Hill IR, Heimbach F, Leeuwangh P, Matthiessen P (eds) Freshwater field tests for hazard assessment of chemicals. CRC Press Inc, New York

40. European Commission (2011) Commission Regulation (EU) No 546/2011 of 10 June 2011 implementing Regulation (EC) No 1107/2009 of the European Parliament and of the Council as regards uniform principles 
for evaluation and authorisation of plant protection products. Official Journal of the European Commission. https://eur-lex.europa.eu/LexUr iServ/LexUriServ.do?uri=OJ:L:2011:155:0127:0175:EN:PDF

41. ECHA (2017) Guidance on Information Requirements and Chemical Safety Assessment. Chapter R.7c: Endpoint specific guidance Version 3.0. https://echa.europa.eu/documents/10162/13632/information_requi rements_r7c_en.pdf/e2e23a98-adb2-4573-b450-cc0dfa7988e5

42. Schlich K, Beule L, Hund-Rinke K (2016) Single versus repeated applications of $\mathrm{CuO}$ and $\mathrm{Ag}$ nanomaterials and their effect on soil microflora. Environ Pollut 215:322-330. https://doi.org/10.1016/j.envpol.2016.05.028

43. Schlich K, Hund-Rinke K (2015) Influence of soil properties on the effect of silver nanomaterials on microbial activity in five soils. Environ Pollut 196:321-330. https://doi.org/10.1016/j.envpol.2014.10.021

44. Schlich K, Klawonn T, Terytze K, Hund-Rinke K (2013) Hazard assessment of a silver nanoparticle in soil applied via sewage sludge. Environ Sci Eur 25(1):17

45. ISO 17155 (2012) Soil quality - determination of abundance and activity of the soil microflora using respiration curves

46. Nordgren A, Bååth E, Söderström B (1988) Evaluation of soil respiration characteristics to assess heavy metal effects on soil microorganisms using glutamic acid as a substrate. Soil Biol Biochem 20(6):949-954. https://doi. org/10.1016/0038-0717(88)90109-5

47. Campbell CD, Grayston SJ, Hirst DJ (1997) Use of rhizosphere carbon sources in sole carbon source tests to discriminate soil microbial communities. J Microbiol Methods 30(1):33-41. https://doi.org/10.1016/S0167 -7012(97)00041-9

48. Wakelin SA, Macdonald LM, Rogers SL, Gregg AL, Bolger TP, Baldock JA (2008) Habitat selective factors influencing the structural composition and functional capacity of microbial communities in agricultural soils. Soil Biol Biochem 40(3):803-813. https://doi.org/10.1016/j.soilbio.2007.10.015

49. Cartwright J, Dzantor EK, Momen B (2016) Soil microbial community profiles and functional diversity in limestone cedar glades. CATENA 147:216-224. https://doi.org/10.1016/j.catena.2016.07.010

50. Li J, Li Y-t, Yang X-d, Zhang J-j, Lin Z-a, Zhao B-q (2015) Microbial community structure and functional metabolic diversity are associated with organic carbon availability in an agricultural soil. J Integr Agric 14(12):2500-2511. https://doi.org/10.1016/S2095-3119(15)61229-1

51. Ma X, Liu M, Li Z (2015) Dynamics of bacterial metabolic profile and community structure during the mineralization of organic carbon in intensive swine farm wastewater. Chilean J Agric Res 75:224-231

52. Banning NC, Lalor BM, Cookson WR, Grigg AH, Murphy DV (2012) Analysis of soil microbial community level physiological profiles in native and post-mining rehabilitation forest: which substrates discriminate? Appl Soil Ecol 56:27-34

53. Creamer RE, Stone D, Berry P, Kuiper I (2016) Measuring respiration profiles of soil microbial communities across Europe using MicroResp $^{\text {TM }}$ method. Appl Soil Ecol 97:36-43. https://doi.org/10.1016/j.apsoi 1.2015.08.004
54. Dick RP, Rasmussen PE, Kerle EA (1988) Influence of long-term residue management on soil enzyme activities in relation to soil chemical properties of a wheat-fallow system. Biol Fertil Soils 6(2):159-164. https://doi. org/10.1007/bf00257667

55. Chae Y, Cui R, Woong Kim S, An G, Jeong S-W, An Y-J (2017) Exoenzyme activity in contaminated soils before and after soil washing: ß-glucosidase activity as a biological indicator of soil health. Ecotoxicol Environ Saf 135:368-374. https://doi.org/10.1016/j.ecoenv.2016.10.007

56. Ahmed AM, Lyautey E, Bonnineau C, Dabrin A, Pesce S (2018) Environmental concentrations of copper, alone or in mixture with arsenic, can impact river sediment microbial community structure and functions. Front Microbiol. https://doi.org/10.3389/fmicb.2018.01852

57. Chae Y, Kim D, An YJ (2018) Effects of fluorine on crops, soil exoenzyme activities, and earthworms in terrestrial ecosystems. Ecotoxicol Environ Saf 151:21-27. https://doi.org/10.1016/j.ecoenv.2017.12.060

58. Konopka A, Oliver L, Turco J (1998) The use of carbon substrate utilization patterns in environmental and ecological microbiology. Microb Ecol 35(2):103-115. https://doi.org/10.1007/s002489900065

59. Smalla K, Wachtendorf U, Heuer H, Liu W-t, Forney L (1998) Analysis of BIOLOG GN substrate utilization patterns by microbial communities. Appl Environ Microbiol 64(4):1220-1225

60. Bell T, Newman JA, Silverman BW, Turner SL, Lilley AK (2005) The contribution of species richness and composition to bacterial services. Nature 436:1157. https://doi.org/10.1038/nature03891

61. Mao J, Luo Y, Teng Y, Li Z (2012) Bioremediation of polycyclic aromatic hydrocarbon-contaminated soil by a bacterial consortium and associated microbial community changes. Int Biodeterior Biodegrad 70:141-147. https://doi.org/10.1016/j.ibiod.2012.03.002

62. Nielsen KM, Johnsen PJ, Bensasson D, Daffonchio D (2007) Release and persistence of extracellular DNA in the environment. Environ Biosaf Res 6(1-2):37-53

63. Zhang XX, Xu ZL, Wu MS, Qian XT, Lin DH, Zhang HJ, Tang J, Zeng T, Yao WJ, Filser J, Li LXY, Sharma VK (2019) Potential environmental risks of nanopesticides: application of $\mathrm{Cu}(\mathrm{OH})(2)$ nanopesticides to soil mitigates the degradation of neonicotinoid thiacloprid. Environ Int 129:42-50. https:// doi.org/10.1016/j.envint.2019.05.022

64. Dennis PG, Kukulies T, Forstner C, Orton TG, Pattison AB (2018) The effects of glyphosate, glufosinate, paraquat and paraquat-diquat on soil microbial activity and bacterial, archaeal and nematode diversity. Sci Rep 8(1):2119. https://doi.org/10.1038/s41598-018-20589-6

\section{Publisher's Note}

Springer Nature remains neutral with regard to jurisdictional claims in published maps and institutional affiliations.

\section{Submit your manuscript to a SpringerOpen ${ }^{\circ}$ journal and benefit from:}

- Convenient online submission

- Rigorous peer review

- Open access: articles freely available online

- High visibility within the field

- Retaining the copyright to your article

Submit your next manuscript at springeropen.com 